\author{
Marquette University \\ e-Publications@Marquette
}

Political Science Faculty Research and

Publications

Political Science, Department of

$10-2019$

\title{
An “Untrammeled Right”? The McCarran Immigration \\ Subcommittee and the Origins of Presidential Authority to \\ Suspend and Restrict Alien Entry Under §1182(f)
}

H. Richard Friman

Marquette University, h.r.friman@marquette.edu

Follow this and additional works at: https://epublications.marquette.edu/polisci_fac

Part of the Political Science Commons

\section{Recommended Citation}

Friman, H. Richard, "An "Untrammeled Right"? The McCarran Immigration Subcommittee and the Origins of Presidential Authority to Suspend and Restrict Alien Entry Under §1182(f)" (2019). Political Science Faculty Research and Publications. 76.

https://epublications.marquette.edu/polisci_fac/76 
Marquette University

e-Publications@Marquette

\title{
Political Science Faculty Research and Publications/College of Arts and Sciences
}

This paper is NOT THE PUBLISHED VERSION; but the author's final, peer-reviewed manuscript. The published version may be accessed by following the link in the citation below.

Journal of Policy History, Vol. 31, No. 4 (October 2019): 433-463. DOI. This article is (C Donald Critchlow and Cambridge University Press and permission has been granted for this version to appear in ePublications@Marquette. Donald Critchlow and Cambridge University Press does not grant permission for this article to be further copied/distributed or hosted elsewhere without express permission from Donald Critchlow and Cambridge University Press.

\section{An "Untrammeled Right"? The McCarran Immigration Subcommittee and the Origins of Presidential Authority to Suspend and Restrict Alien Entry Under §1182(f)}

\author{
H. Richard Friman \\ Marquette University
}

\section{Abstract}

The language of Section 212(e) of the 1952 Immigration and Nationality Act, 8 U.S.C. §1182(f), contains a sweeping authorization of presidential discretion to suspend and restrict alien entry into the United States. Senator Pat McCarran (D-NV) first introduced the subsection in 1950 as part of the omnibus immigration bill drafted by his Judiciary Committee's immigration subcommittee. The specific origins of the language and the original intent behind the subsection remain missing pieces in the extensive scholarly literature on the 1952 INA and legislative history as explored by the courts. This article reveals that the subcommittee modeled the 
subsection on the sixth proviso of the 1917 Immigration Act, the May 1918 Wartime Measure, and a selective interpretation of Supreme Court precedent. The article reveals further that the original intent behind the subsection was to close perceived loopholes in existing law enabling entry by displaced persons and Communist governmental officials.

\section{Keywords}

immigration, alien entry, refugees, subversives, presidential authority

On April 25, 1952, the last day of the House floor debate over the McCarran-Walter omnibus immigration bill (H.R. 5678), Representative Abraham Multer (D-NY) introduced what he described as a "simple" amendment. ${ }^{1}$ For well over a year, opponents in the House and Senate had argued against the bill's provisions with little effect. With the rival Humphrey-Lehman immigration bill stalled in the Senate, Multer and Representative Emanuel Celler (D-NY) turned to a last-ditch effort to modify McCarran-Walter. Multer's amendment focused on the bill's controversial Section 212(e), which, he noted, posited "that at any time the President finds the entry of any aliens or class of aliens would be detrimental to the interests of the United States he may by proclamation suspend the entry of those aliens." The amendment called for language limiting such authority to "when the United States is at war or during a national emergency declared by the President."2

Other provisions under McCarran-Walter had reaffirmed and expanded existing law on specific categories of aliens excluded from entering the country. Yet Section 212(e) was different. The House Judiciary Committee's Report to accompany H.R. 5678 released in February 1952 revealed no counterpart to the proposed subsection in existing law. ${ }^{3}$ In the report's minority opinion, Celler wrote that 212(e) was "an abdication by Congress of the control of immigration" and a "dangerous substitution of government by law, by government by man."4 Speaking on behalf of the Multer amendment two months later, Celler reiterated these themes and expressed his concern that with such language "the President is given an untrammeled right, an uninhibited right to suspend immigration entirely." ${ }^{5}$ The Multer amendment failed as did similar efforts to change the language in the Senate. ${ }^{6}$ The broad authority under Section 212(e) remained in McCarran-Walter becoming part of the 1952 Immigration and Nationality Act (INA) and is now known as 8 U.S.C. §1182(f).

Despite the extensive scholarship on the origins and impact of the 1952 INA in American immigration policy, this portion of the act and particularly the intent of those who drafted and supported this measure remain underexplored. The literature on McCarran-Walter includes detailed analyses of the omnibus bill's reaffirmation of the national-origins quota system as well as steps ending exclusion and extension of quotas to Asians, expanding excludable and deportable classes of aliens, and removing racial, national, and gendered barriers to citizenship. ${ }^{7}$ Scholars have broadly traced the origins of McCarran-Walter to the work of Senator Pat McCarran (D-NV) and the special investigative immigration subcommittee of the Judiciary Committee coordinated by his staff director Richard Arens. ${ }^{8}$ Yet the specific origins of the language and the original intent behind Section $212(e)$ remain missing pieces in this literature.

Similarly, the legislative history of $\S 1182(\mathrm{f})$ as explored by the courts has done little to fill this gap. ${ }^{9}$ Before 2017, the most important piece of the "limited case law" on the subsection was the U.S. 
Supreme Court's brief discussion in the 1993 Sale v. Haitian Center Council Inc. concerning President George W. Bush's Executive Order on the interdiction of Haitian refugees. ${ }^{10}$ Writing for the majority, Justice John Paul Stevens noted that the statute "granted the President ample power to establish a naval blockade" to deny entry to "illegal Haitian migrants." ${ }^{11}$ But neither the majority nor dissenting justices delved into the origins of the statute's language or the original congressional intent. ${ }^{12}$ Although case law on $\S 1182$ (f) increased dramatically in 2017 with the legal challenges to President Donald J. Trump's travel ban, these gaps remained. Unlike in Sale, the courts in 2017 and 2018 in Hawaii et al. v. Trump et al., and Trump et al. v. Hawaii et al. looked more closely into the origins of this subsection in McCarran-Walter. Yet as discussed below in addressing origins, both the Ninth District and U.S. Supreme Court limited their focus to, and drew contending interpretations from, only one small part of floor debate over the Multer amendment. ${ }^{13}$

In contrast to the conventional focus on McCarran-Walter by scholars and the courts, this article reveals that understanding the language and intent behind §1182(f) requires a wider exploratory net. As discussed below, McCarran first introduced Section 212(e) on April 20, 1950, as part of the omnibus immigration bill, S. 3455, drafted by the Judiciary Committee's immigration subcommittee he chaired. The full text of 212(e) proposed that:

Whenever the President finds that the entry of any aliens or of any class of aliens into the United States would be detrimental to the interests of the United States he may by proclamation, and for such period as he shall deem necessary suspend the entry of all aliens or any class of aliens be they immigrants or nonimmigrants, or impose on the entry of aliens any restrictions he may deem appropriate."14

This is the language that survived the subsequent deliberative process intact and became $§ 1182(f)$. I argue that McCarran and the subcommittee modeled the language of this subsection on three sources. The first was an obsolete provision of presidential discretionary authority over entry by Japanese laborers introduced in 1907 and later reaffirmed under the 1917 Immigration Act. The second was existing presidential authority by proclamation over alien entry and exit during periods of war and national emergency under the May 1918 Wartime Measure, as amended. The third was a selective interpretation of Supreme Court decisions on congressional and presidential authority over alien entry.

Compared to constraints on discretion under existing law, the sweeping presidential authority to suspend or restrict entry proposed under Section 212(e) was new, and as such poses a puzzle as to the drafters' intent. Through the 1940s, Congress had fought a series of battles seeking to rein in President Franklin D. Roosevelt's legacy of expanding executive branch power. Measures such as the 1946 Administrative Procedure Act introduced extensive congressional oversight of federal administrative agencies' procedures and practices. ${ }^{15}$ As McCarran argued on March 12, 1946, on behalf of the Committee of the Judiciary in support of the proposed act, "The law is the thing that makes democracy vital. This is not a Government of men. It is a Government of law." ${ }^{16}$ Years later the irony of McCarran's shift from this position to the sweeping language of Section 212(e) in McCarran-Walter was not lost on the immigration bill's opponents. ${ }^{17}$ 
As seen above, Celler's minority opinion in the House Judiciary Committee's Report on McCarranWalter used McCarran's words on the importance of law and the need for limits on executive power to argue against 212(e). In the Senate, Hubert Humphrey (D-MN) and Herbert Lehman (D-NY) pointedly argued that the McCarran-Walter supporters were "among those who constantly are speaking of usurpation of power by the Executive and of the importance of constitutional checks and of the due process of law."18 Similarly, the Truman administration's legislative review of the proposed INA observed that language on sweeping presidential authority in McCarran-Walter's Section 212(e) contrasted with "provisions which would tend to place the Executive agencies concerned with immigration [specifically the State Department's Visa Division and the Justice Department's Immigration and Naturalization Service] under closer supervision and control by the Congress." ${ }^{19}$

I argue that the intent of McCarran and the subcommittee with the language of 212(e) was twofold. First, the language was intended as a counterweight to presidential actions and congressional legislation expanding entry for displaced persons, especially European Jewish refugees. For members of the subcommittee, these aliens posed cultural, criminal, subversive, and other threats to the United States. Second, the language was intended to address loopholes in existing law seen by the subcommittee as allowing Communists to enter the country under the protected class of foreign governmental officials. McCarran and the subcommittee introduced the language of Section 212(e) as an additional layer of restriction to address these shortcomings.

The remainder of this article expands on these arguments. The first section explores the origins of the subsection's language and how it was modeled on existing law and selective interpretations of decisions by the Supreme Court. The second section addresses the original intent of the immigration subcommittee in introducing the language by tracing subcommittee concerns to earlier and concurrent debates over displaced-persons legislation and fears of subversive entry through loopholes for foreign officials in existing law. The third section extends the analysis beyond the first introduction of the subsection in 1950 and turns to two incidents in the final congressional floor debates over McCarranWalter that offer further insights into the issue of original intent.

\section{THE ORIGINS OF 212(E) LANGUAGE}

Drawing on a "historical-institutionalist approach," Daniel Tichenor argues that the provisions of McCarran-Walter are best understood through the lens of Cold War pressures and powerful restrictionist "'committee barons'" able to block the efforts of expanding coalitions of immigration defenders and expert challenges to the racial necessity of alien exclusion. ${ }^{20}$ This approach offers a useful starting point. McCarran clearly epitomized the restrictive congressional committee baron. ${ }^{21}$ McCarran filled the immigration subcommittee with restrictionist anticommunist members of the Judiciary Committee, including James Eastland (D-MS), and relied on his like-minded staff such as Arens to manage the subcommittee's investigations. As discussed below, Arens played a lead role in conducting subcommittee hearings on displaced persons and subversive aliens, drafting the subcommittee's omnibus immigration bill and its accompanying report, and in subsequent Senate hearings over McCarran-Walter.

That McCarran and the immigration subcommittee were responsible for the omnibus bill still begs the question of how they derived the language for 212 (e). The answer to this question is all the more 
difficult given that no explicit discussion of the subsection's origins appears in the subcommittee's detailed, 900-plus page report accompanying the omnibus bill or in subsequent hearings or testimony. ${ }^{22}$ Scholars of American political development point to the impact of institutionalized past choices as well as agency of political actors on the direction of policy. ${ }^{23}$ The legislative history of the origins of the omnibus bill suggests that both were at play in the case of 212(e). For McCarran and the immigration subcommittee, the 1917 and 1924 Immigration acts comprised the primary baseline of existing law on exclusion and admissibility and were emblematic of its problems. Moreover, the subcommittee report argued that an omnibus bill was necessary in light of the additional " 200 additional legislative enactments . . . a number of treaties, Executive orders, proclamations, and a great many rules, regulations, and operations instructions" on immigration, not including the array of measures on naturalization. ${ }^{24}$ Using the comprehensive immigration acts as the framework on which to build a new omnibus bill allowed the subcommittee to argue to other members of Congress that they were retaining the best of existing law while addressing its critical gaps. Reviewing the legislative history of McCarran's 1950 omnibus bill suggests that the subcommittee modeled the language of Section 212(e) on the following sources: the sixth proviso of the 1917 Immigration Act; the May 1918 Wartime Measure, as amended; and selective interpretations of U.S. Supreme Court rulings on the plenary power of Congress and the Executive to restrict alien entry.

\section{The Comprehensive Acts}

The immigration subcommittee report framed the issue of alien entry in terms of two categories, excludable and admissible aliens. The subcommittee used the 1917 Immigration Act, especially Section 3 , as its primary entry point into the subject of excludable aliens. This section listed multiple classes of aliens automatically denied entry, such as convicted criminals, paupers, and the mentally and physically infirm. But the section also listed a series of provisos that established "exceptions to the excludable classes," such as persons convicted of political offenses, and "all aliens who were accredited officials of foreign governments, and their suites, families, or guests." 25 The subcommittee report explored each of the excludable classes and the provisos in detail and discussed recommendations for changes under a proposed omnibus bill. These changes included expanding the number and scope of the excludable classes, particularly to include Communists and other subversives, and narrowing the exceptions to exclusion. ${ }^{26}$

The subcommittee used the 1924 Immigration Act as its baseline for addressing the relative admissibility of aliens based on their national origin. The act distinguished between quota immigrants subject to annual limits on entry and nonquota immigrants, primarily from the Western hemisphere, who were exempt from the national-origins quota system. Nonimmigrant aliens such as tourists and visitors, those in transit, foreign government officials, and alien seamen were also exempt from the national-origins quotas. ${ }^{27}$ The subcommittee report reviewed each of these categories and offered recommendations on ways in which the system should be modified under the omnibus bill. The subcommittee reaffirmed the basic structure of the national-origins system, especially its privileging of Northern and Western Europeans, added Asians to the system by allowing limited alien entry from the "Asia-Pacific triangle," and emphasized the need for denying access to those aliens who regardless of their immigrant, nonimmigrant, and/or protected status fell within the excludable classes as defined by the subcommittee's proposed changes to the 1917 Act. $^{28}$ 
The subcommittee report's primary reference to language that would become Section 212(e) appeared in the discussion of modifying the sixth proviso in Section 3 of the 1917 Act. ${ }^{29}$ The report described this proviso as unique. It was "the only one [in the $1917 \mathrm{Act}$ ] that permits the prohibition of certain aliens rather than the entry of otherwise excludable aliens." ${ }^{30}$ The proviso empowered the President to prohibit entry by aliens seeking to access the continental United States through third countries, U.S. insular possessions, or the Panama Canal zone, when he was "satisfied" that passports issued by foreign governments were "being used" for such a "purpose . . . to the detriment of labor conditions therein." 31 The proviso's language contained no conditions limiting discretionary authority to war or proclamations of national emergency, nor did it contain any criteria for presidential determinations of detrimental effect.

The subcommittee report noted that the members had learned from a representative of the Immigration and Naturalization Service that the language of the sixth proviso actually predated 1917. ${ }^{32}$ Appearing in the Immigration Act of February 20, 1907, the Gentleman's Agreement between the United States and Japan, and President Theodore Roosevelt's Executive Order 589 of March 14, 1907, the language was intended to target Japanese laborers evading exclusion by entering the U.S. through Mexico, Canada, and Hawaii. ${ }^{33}$ The report noted that subsequent changes in immigration law and practice had solved this problem. The introduction of the national-origins quota system and restrictive visa provisions under the 1924 Immigration Act addressed the transit practice, and the changing relationship with Japan had included President Harry Truman's revocation of Roosevelt's original Executive Order in October $1948 .^{34}$

As a result, the subcommittee concluded that the sixth proviso was no longer necessary and the subcommittee report called for its deletion. But in the report's next sentence the subcommittee noted that the omnibus immigration bill would be adding new language in place of the sixth proviso. Without any further explanation or detail, the report stated that "a general provision is being included in the proposed [omnibus] law to permit the President to suspend any and all immigration whenever he finds such action to be desirable in the best interest of the country." ${ }^{35}$ In the report's appendix summarizing provisions of the omnibus bill, the subcommittee noted further that "the President is given the power to suspend or restrict entry of any alien or class of aliens whose admission he finds to be detrimental to the interests of the United States." ${ }^{36}$ Like that of the sixth proviso, this language linked discretionary authority to restrict alien entry to presidential determinations of detrimental effect. But the new provision was much broader.

\section{Discretionary Authority in Wartime or Proclamations of National Emergency}

Although the sixth proviso informed the language of the Section 212(e), the model for the mechanism of presidential proclamation to invoke such discretionary authority over alien entry found in the subsection lies elsewhere. Here the subcommittee appeared to turn to language found in existing law imposing "extraordinary controls" on subversive aliens in times of war and national emergency. ${ }^{37}$ The subcommittee observed that as early as 1798 the "concern of Congress" with subversion had resulted in laws authorizing the President to take such steps against subversive aliens by proclamation in the name of "public safety." 38 Where the Alien Enemy Act of 1798 had focused on "the alien resident in time of war or threatened invasion," subsequent acts of Congress had included authority to impose additional controls on alien entry. ${ }^{39}$ Under the May 22, 1918, Wartime Immigration Act, as amended 
June 21, 1941, Congress authorized the President to exclude aliens "upon finding it in the interests of the United States" during periods of war or presidential proclamation of national emergency. ${ }^{40}$ President Franklin D. Roosevelt had proclaimed such an emergency on May 27, 1941, and called for additional controls on alien entry by "Proclamation 2523 on November 14, 1941."41 The subcommittee report noted further that regulations introduced by the Attorney General at this time "continue in effect as part of the immigration laws, since the national emergency has never been terminated and a state of war still exists." 42

Recent public scholarship on Section 212(e) contends that its origins lie in the long history of existing law, as reviewed by the immigration subcommittee in its report, empowering the President to restrict alien entry by proclamation in times of war and national emergency. ${ }^{43}$ This claim is only partially correct. The subcommittee explicitly included the language of the May 22, 1918, Wartime Immigration Act, as amended, in the 1950 omnibus immigration bill as Section 216(a), ${ }^{44}$ and discussed this linkage in the report. ${ }^{45}$ Yet, the subcommittee made no such link between this history and $212(\mathrm{e})$, either as a basic peacetime version of wartime presidential authority or a step necessitated by the pending end of the wartime state of emergency. ${ }^{46}$ Instead, the subcommittee added portions of the language on presidential proclamation to the framework of the sixth proviso.

\section{Plenary Power}

A third possible source for the sweeping language of Section 212(e) lies in the subcommittee's reading of court decisions at the time of the report's preparation. ${ }^{47}$ Drawing on the Supreme Court's January 16, 1950, arguments in Knauff v. Shaughnessy, as grounded in Nishimura Ekiu v. United States, the subcommittee report contended: "It is well established by decisions of the Supreme Court that every sovereign nation has the power, inherent in its sovereignty, to forbid the entrance of aliens or to admit them upon such conditions as it may prescribe." 48 But where the court in Knauff went on to emphasize that such authority was "inherent in the executive power to control the foreign affairs of the nation," the subcommittee report adopted a different tack. ${ }^{49}$ Drawing on the court's 1914 ruling in Lapina $v$. Williams, the subcommittee stressed that "the authority of Congress over the admission of aliens [to the United States] is plenary." 50 Congress may "exclude them all together or prescribe the terms upon which they may enter and remain in the country." ${ }^{11}$

Earlier sections of the subcommittee report dealing with excludable classes were written before the Knauff ruling. ${ }^{52}$ Here the subcommittee pointed to the 1889 Chinese exclusion case of Chae Chan Ping v. United States, where "the Supreme Court held that the power of the Congress to exclude aliens from the country is an incident of sovereignty." 53 The subcommittee argued further that "the courts have also held that it is proper for the Congress to delegate its power to control immigration to officials who may have discretionary power and who are made sole and exclusive judges of the existence of facts concerning the entrance of immigrants under the immigration laws." 54

These arguments reinforced a central theme in the subcommittee report that the "concern of Congress" had been at the forefront of existing law empowering the President to address threats to public safety posed by alien entry. ${ }^{55}$ Citing this plenary power, the subcommittee presented its recommendations for "additional restrictions on alien subversives" to be included in the omnibus bill. ${ }^{56}$ These recommendations included expanding the discretionary power of consular officials, the Commissioner of Immigration, the Attorney General, and, as discussed below in cases of foreign 
government officials, the President. ${ }^{57}$ Yet, once again the report made no mention of the language of Section 212(e) in this context. That said, the subcommittee's interpretation of the plenary power of Congress over alien admission would allow for the creation of such language empowering the President to restrict alien entry on determination that such entry was detrimental to the United States.

\section{THE TARGETS OF DISCRETIONARY EXCLUSION}

On the surface, the language of Section 212(e) was a blanket authorization to restrict alien entry. But this interpretation fails to capture the subcommittee's concerns with particular groups. In hearings held by the subcommittee from 1947 to 1950, references to the threat posed by two groups stood out: refugees, especially European Jews and Communist subversives entering the United States through the refugee process; and Communist subversive foreign government officials and representatives of international organizations entering the United States through proviso loopholes in the 1917 Immigration Act, as amended, and the 1945 International Organizations Immunities Act.

\section{The Refugee Threat}

By the late 1940s, McCarran and the immigration subcommittee were at the forefront of efforts in the Senate to limit the entry of displaced persons into the United States. These efforts came in the context of earlier restrictionist successes during the 1930s in blocking access by the rising number of displaced persons in Europe. Congressional backlash and opposition within the Department of State had stymied efforts by advocates of admission for predominantly Jewish refugees from Germany during the late 1930s and early 1940s. ${ }^{58}$ In 1944, President Roosevelt took a different tack by establishing the War Refugee Board by Executive Order 9417 of January 22 and announcing to Congress on June 12 that an emergency, temporary shelter for up to one thousand refugees had been established at Fort Ontario in Oswego, New York. ${ }^{59}$ Senator Rufus C. Holman (R-OR), a noted anti-Semite and restrictionist, captured the opposition's reaction as he challenged the constitutionality of such a step "to set aside and violate the laws of Congress restricting immigration into our country." 60

On December 22, 1945, President Harry S. Truman took further action. Noting the magnitude of the population dislocation problem in Europe and the important but "small" steps at Fort Oswego, Truman issued a Directive on Immigration calling for the establishment of "consular facilities at or near displaced persons and refugee assembly centers in the American zones of occupation" in Europe. Consular officials would determine eligibility for immigration under existing national origin quotas and provisions on excludable classes as well as "simplify" and "hasten the process of issuing visas." 61 Yet by working within the existing quota system and relying on officials resistant to expanded immigration, the impact of the directive was limited to "only 5,000 displaced persons" admitted "in the first nine months of 1946." 62 Dissatisfaction over these results prompted calls by Truman and supporters of displaced persons for new legislative efforts beginning in 1947 that culminated in the 1948 Displaced Person Act (DPA). ${ }^{63}$

McCarran, along with Senator Chapman Revercomb (R-WV), comprised the initial core of the Judiciary Committee's special immigration subcommittee, established on July 26,1947 , to investigate the state of the country's immigration laws and to prepare a separate report on the displaced persons issue. ${ }^{64}$ The latter took initial priority. ${ }^{65}$ The subcommittee report and accompanying displaced persons bill introduced in the Senate on March 2, 1948, set a baseline for a more restrictionist response to the 
displaced persons problem. The report noted that refugees were suspect as Communist subversives and a likely economic burden on the United States. Moreover, the report stated that refugees predominantly consisted of Jews that were manipulating the displaced-persons eligibility process through fraud, few being left in the occupation zones by the date of Truman's 1945 directive, and through undue political influence by their wealthy supporters. ${ }^{66}$ Similar themes had been raised by Arens during his questioning of witnesses during an early July 1947 subcommittee hearing over a bill to allow the entry of displaced persons orphaned by the war. ${ }^{67}$ To address these perceived shortcomings, the subcommittee bill included restrictive measures such as limiting the numbers of displaced persons to one hundred thousand over two years and restricting access to those "people registered as displaced persons" as of December 22, $1945 .{ }^{68}$ The final congressional compromise in the DPA retained this eligibility date with few exceptions, but doubled the overall cap by counting refugee admissions against future national quotas - in other words, letting in more refugees from countries otherwise limited by reducing, in theory, how many could come from those countries in future years. ${ }^{69}$ Truman "reluctantly" signed the DPA on June 25, 1948, observing that it "discriminates in callous fashion against displaced persons of the Jewish faith." 70 Shortly thereafter, supporters of displaced persons turned to efforts to amend the DPA.

McCarran worked hard to derail these efforts using his position as chair of the Judiciary Committee from 1949 on to delay consideration of proposed legislation. ${ }^{71}$ Michael Ybarra writes that opposition to access by displaced Jews, and to Jews more broadly, underpinned McCarran's legislative efforts and public rhetoric about the threat of Communist subversives and other undesirables posing as refugees. ${ }^{72}$ After multiple delaying tactics in 1949 and with an array of restrictionist amendments, the deliberations over refugee legislation finally made it out of committee to the Senate floor in early 1950. McCarran again worked to derail legislation with more delays and amendments but ultimately without success. In early April, the Senate passed a new displaced-persons bill expanding refugee access. $^{73}$

After Senator Revercomb lost his seat in the 1948 elections, McCarran became chair of the immigration subcommittee as well as the Judiciary Committee in 1949. ${ }^{74}$ During subcommittee hearings over displaced persons held from March 1949 through March 1950, McCarran had Arens take the lead in selecting witnesses and using targeted questions to make the case against any expansion of refugee access. Arens and McCarran repeatedly utilized witness testimony during the hearings to point to the number of Jews admitted under the DPA as proof that the act was not discriminatory. They also turned to the same numbers to stress that Jews in large numbers were using fraudulent documents to falsely claim presence in the allied occupied zones before the Truman Directive date necessary for eligibility. ${ }^{75}$ Arens utilized witness testimony from subpoenaed members and disgruntled former members of the Displaced Persons Commission to raise questions of Jewish influence over the leadership and decision-making processes in determining eligibility, pressuring consular and immigration officials, and directing efforts to amend the DPA. ${ }^{76}$ Arens and members of the subcommittee such as James Eastland rejected the distinction made by commissioners between displaced persons turning to limited black market participation to survive and large-scale illicit activities, arguing that such distinctions masked widespread criminal proclivity among Jewish refugees in addition to their alleged document fraud. ${ }^{77}$ Finally, subcommittee members repeatedly posed questions, and echoed supporting answers, about the inherent threats in changing the baseline dates 
for eligibility as opening the door to even greater threats of Jewish and other Communist subversives entering the United States under the guise of displaced persons. ${ }^{78}$

Arens and McCarran vehemently rejected or simply ignored the efforts by the few witnesses such as Celler who tried to push back against the tenor of the hearings. ${ }^{79}$ As Arens noted after a particularly contentious exchange with Harry Rosenfield of the Displaced Persons Commission, "every patriotic American in this country ought to get on his knees every night and thank the Good Lord that we have the senior senator from Nevada who has been waging this fight against tremendous odds and against a million dollar lobby.... There is no question but what there is a complete breakdown in the administration of this law, so that black marketers, subversives, criminals, undesirables are gaining admission into this country." 80

The subcommittee hearings continued through March 1950, reaffirming conclusions that Arens and McCarran had already reached on the need for restrictive measures against displaced persons. The Judiciary Committee had already submitted its version of the House bill amending the DPA along with a supporting report drafted by Arens on January 25, and the Senate floor debate over the bill began on February 28. ${ }^{81}$ At the same time as McCarran was fighting a losing battle to derail the DPA, the immigration subcommittee was working on its larger report in support of McCarran's draft omnibus immigration bill. ${ }^{82}$

The final report of the immigration subcommittee that accompanied the omnibus immigration bill was less strident on the refugee issue but in several ways reaffirmed earlier arguments that the country was at risk. The subcommittee posited the national-origins quota system as an essential part of the omnibus immigration bill, acknowledging and approving the fact that this system had privileged Western and Northern Europeans and tightly restricted entry of less "assimilable" aliens from Southern and Eastern European countries. ${ }^{83}$ The subcommittee further noted the dramatic rise of "new" immigrant populations dominated by "Italians, the Slavs and Jews." ${ }^{44}$ The discussion of Jewish immigration was particularly slanted conveying a rising threat. The report mixed an array of baselines and trends noting, for example, that: while Jews comprised less than 4 percent of the U.S. population in 1937, they accounted for "between 25 and 77 percent of total net immigration" since that time. Moreover, their population growth since 1877 of 21 percent had outstripped that of the overall United States by a factor of seven and had increased 2.5 million since $1881 .^{85}$ The report also noted that Jewish refugees accounted for 26 percent of those admitted under the 1948 DPA. ${ }^{86}$

The report made only brief additional references to the refugee issue. For example, one section noted the visa set-asides in the 1948 DPA for refugees who had worked in agriculture and were likely to continue to do so in the United States as precedent for adding greater occupational "selectivity" in future immigration law. ${ }^{87}$ Yet no mention was made that McCarran and Revercomb had introduced this provision in 1948 as way of discriminating against Jews who were less likely to qualify due to other occupational pursuits. ${ }^{88}$ The subcommittee report also briefly discussed displaced persons in the context of the national-origins quotas. Although the initial impact of DPA legislation would be temporary, the report stated, refugee access created "confusion" in the distribution of preference categories for a given country and mortgaged alien entry against future quotas. ${ }^{89}$ Moreover, refugee provisions would clash with other set-asides in the Austrian and German national-origin quotas for ethnic Germans under the 1948 DPA. The report made no mention of the contentious issue of Jewish 
discrimination or the efforts of McCarran and subcommittee members to reclassify ethnic Germans born in Eastern European countries as displaced persons and therefore eligible for entry under the DPA. ${ }^{90}$

McCarran's losing battle against displaced-persons legislation helps to explain why the subcommittee included Section 212(e) in the omnibus bill. In 1944 and 1945, Presidents Roosevelt and Truman had used the power of the office to circumvent congressional opposition and existing law to expand access for displaced persons. The language of 212(e) offered a future restrictionist president a way to stop refugees from coming into the United States. The linkage and the immigration subcommittee's focus on the threats posed by Jewish displaced persons was not lost on the opposition. Jewish groups had been at the forefront of lobbying on behalf of the 1948 DPA and its expansion. ${ }^{91}$ By 1951 they were continuing this role in public hearings over McCarran's omnibus immigration bill, calling attention to and opposing the unprecedented expansion of presidential authority proposed in Section 212(e). ${ }^{92}$ Jewish members of Congress, including McCarran's primary opponent in the 1950 refugee clash, Senator Lehman, as well as Celler and Multer in the House, were also among the leading voices challenging the sweeping language of 212(e). ${ }^{93}$

\section{Foreign Officials and the Subversive Threat}

The immigration subcommittee's focus on inroads of alien subversion was not limited to displaced persons. During the late 1940s, McCarran was also at the forefront of efforts in the Senate to introduce legislation informed by the subcommittee's investigations of how loopholes in existing immigration law had intensified the Communist threat to national security. Part III of the subcommittee's final report on immigration focused on "Subversives." Here the subcommittee framed its analysis of Communism as "an alien force," "an international conspiracy" that was infiltrating "our borders for the purpose of overthrowing the democratic Government of the United States by force, violence, and subversion." 94 Based on the subcommittee's recommendations, the omnibus immigration bill added multiple categories for Communists and other subversives to the classes of aliens excluded from entry. ${ }^{95}$ However, the subcommittee also argued that as long as exceptions to exclusion existed that offered paths to entry to Communists, simply expanding the scope of excludable classes was not enough. These other paths had to be addressed.

Based on its investigations, the subcommittee noted the lack of restrictions on foreign government officials and representatives of international organizations as a particular security threat. ${ }^{96}$ Specifically, the 1917 Immigration Act's tenth proviso had exempted "accredited officials of foreign government officials" along with "their suites, families, or guests" from the classes of exclusion. ${ }^{97}$ The 1924 Immigration Act designated such persons as nonimmigrants, exempt from the visa provisions affecting quota and nonquota immigrants, and made no change in their exemption from exclusion. ${ }^{98}$ In December 1945, the International Organization Immunities Act extended these privileges to officers and employees of organizations and their immediate family members. ${ }^{99}$

The subcommittee began to target these loopholes in 1949. On April 25, McCarran introduced legislation, S. 1694, to better exclude and deport subversive aliens. ${ }^{100}$ Noting the initial findings of the immigration subcommittee, McCarran argued that subversive Communist aliens, coordinated by the Kremlin, were taking advantage of lax immigration laws to infiltrate the United States. McCarran emphasized the "backdoors" of "exceptions and provisos" in existing law for representatives of 
international organizations and commissions. These enabled entries by aliens who were feeding the communist "lifeline" in the United States and supporting the "fifth column" threat to national security. Responding to this threat, he argued, would require an expansion of "government power" to "plug the loopholes" in existing law. ${ }^{101}$ McCarran's bill, subsumed with more detail on May 11 into a second McCarran bill, S. 1832, proposed amending existing law on anarchist exclusion and expulsion to address the subversive threat. ${ }^{102}$

The subcommittee based the McCarran bills on the Immigration Act of October 16, 1918, as amended, which had expanded the scope of excludable and deportable aliens on grounds of anarchistic behaviors and affiliations beyond that first introduced in $1903 .{ }^{103}$ McCarran's bill S. 1832 established a broader category of activities "subversive to national security" and authorized the Attorney General to determine the parameters of this category as well as identify "every [subversive] association, society, and group" "on the basis of evidence satisfactory to him."104 The bill further empowered the Attorney General to exclude and deport, without limitation or interference, "any alien," including tenth proviso aliens, he "knows or believes" to be seeking to enter, or has entered, the United States to engage in subversive activities. ${ }^{105}$

During public hearings over the next five months, the subcommittee questioned witnesses who expounded on the Communist threat and called for action along the lines of the McCarran bill. ${ }^{106}$ As in the DPA hearings, Arens coordinated the witnesses and had them repeat and expand on portions of their testimony when it supported the subcommittee's concerns. ${ }^{107}$ Communists and former Communists appearing under subpoena responded in the affirmative when Arens asked whether subversives were entering the United States as "affiliates or invitees of the United Nations" and other international organizations, and the extent to which "Communist activities in the United States are under the direction, control and supervision of the officials of iron-curtain countries who are in the United States." 108 L. Paul Wining, General Counsel for the Immigration and Naturalization Service, and consultant to the subcommittee in drafting the McCarran bill, pointed to the constraining effects of the tenth proviso on excluding alien subversives. ${ }^{109}$ The subcommittee also subpoenaed the Secretary of State and the Attorney General for access to information in files on officials and employees of foreign governments and the United Nations engaged in subversive activity in the United States. ${ }^{110}$ Arens used subsequent testimony by AG Thomas Clark and State Department representatives to repeatedly call attention to the tenth proviso and the ease of access by subversive foreign officials. ${ }^{111}$

Despite the extensive hearings, McCarran's bill went no further in 1949. As part of a delaying tactic on the revisions of the DPA, McCarran had left the country from mid-September to early December for a tour of Europe to assess the displaced persons issue. ${ }^{112}$ With McCarran away, the subcommittee returned to drafting its immigration report and incorporated the findings of the hearings into brief chapters on the subversive threat and the shortfalls of existing law. ${ }^{113}$ As noted in the Congressional Quarterly Almanac, the 1950 omnibus immigration bill "included all of S. 1832." 114 Yet this conclusion was incorrect. The subcommittee's recommendations and the omnibus bill did not include the 1949 proposals for broadly empowering the Attorney General to exclude or deport any alien on grounds of subversion. ${ }^{115}$ Instead, the subcommittee's approach had become more nuanced.

The subcommittee report proposed narrowing the scope of the tenth proviso by disaggregating its privileged class. The subcommittee recommended that some previously protected aliens such as 
"guests" of foreign officials be removed from nonimmigrant status. Those remaining would be divided into subcategories to better allow for determinations of privilege and exemption from exclusion. ${ }^{116}$ The subcommittee proposed that the exclusion of high-level foreign officials and representatives, such as "Ambassadors, public ministers, and career diplomatic or consular officials," would be the purview of the President. ${ }^{117}$ Specifically, the subcommittee proposed that the President be empowered to restrict entry for such officials "where it is known that they seek to enter the United States to engage in activities prejudicial to the public interest or which will endanger the public welfare or safety [emphasis added]." 118 In language that would also be incorporated into the omnibus immigration bill, the subcommittee noted further that "Consistent with Constitutional limitations, such authority may be exercised only under such rules and regulations as the President deems to be necessary." ${ }^{119}$ All other tenth proviso aliens could be denied entry by consular officials and the Commissioner of Immigration on less stringent standards. ${ }^{120}$ Here authorities could deny entry where the alien's activities are "believed to be prejudicial [emphasis added]" or "where it is known or there is reason to believe [emphasis added]" their activities were "considered to be subversive to national security." 121

Despite the extensive discussion of the recommended changes in executive authority to narrow the tenth proviso loophole, the subcommittee report made no reference to the ability of the President to restrict entry of the highest foreign officials and international organization representatives if their subversive intent was believed but not known. The sweeping language of Section 212(e) would give the President such authority. Yet the subcommittee report never explicitly made this argument; the closest it came was in summarizing the omnibus bill in the appendix. Here the report briefly reviewed the Section 3 provisos of the 1917 Act as "retained, modified, changed or repealed" in the omnibus bill. ${ }^{122}$ Only five remained of the original ten provisos and of these only two were unchanged. The summary noted that the exemption from exclusion for those convicted of a "purely political offense" and the exemption for "foreign-government and international organization officials" would be "continued." 123 Yet as discussed above, the summary was misleading as the latter exemption had been narrowed considerably. The next and last sentence of this part of the summary appeared as a catchall statement that had the potential to narrow entry by admissible aliens even further. Here the appendix inserted the summary language of 212(e) noted above: "The President is given the power to suspend or restrict entry of any alien or class of aliens whose admission he finds to be detrimental to the interests of the United States."124

\section{REVISITING INTENT}

Although opponents of McCarran-Water repeatedly rejected Section 212(e), few examples exist of congressional supporters speaking on behalf of the proposed language. In April and May 1952, opposition efforts to amend McCarran-Walter in the final floor debates in the House and Senate included two incidents that offer further insight into the extent of presidential authority originally envisioned under subsection. The first is the debate over the Multer Amendment in the House, the second is the deal on technical amendments reached between McCarran and Humphrey in the Senate. Beyond broadly noting that last-ditch efforts to amend McCarran-Walter failed, scholars have paid little attention to either incident. In the 2017-18 travel ban cases, the courts narrowly turned to part of the first incident and made no mention of the other. ${ }^{125}$ 


\section{Backdrop}

Efforts to determine McCarran's as well as broader congressional intent behind Section 212(e) in the legislative history from the time that he introduced the omnibus immigration bill in April 1950 to the final passage of McCarran-Walter are challenging at best. Deliberations over an array of internalsecurity bills and investigations and the impact of the onset of the Korean War delayed hearings until March 1951. ${ }^{126}$ As subsequent iterations of the McCarran-Walter bill moved through Congress in 1951 and early 1952, the original 1950 language of Section 212(e) remained unchanged. ${ }^{127}$ During this period, members of the subcommittee, the Judiciary Committee, and restrictionist supporters in the Senate and House lauded McCarran-Walter but made no mention of this specific provision of the bill in hearings or floor remarks. This pattern persisted even as opponents attacked the subsection as an unprecedented expansion of presidential power to restrict all immigration. ${ }^{128}$

In the absence of a restrictionist response, the opposition moved beyond simply rejecting the measure and sought to fight a rearguard action limiting its potential impact. In hearings held on McCarranWalter in 1951, the House and Senate Judiciary Committee minority reports on McCarran-Walter released in early 1952, and days of floor testimony during May 1952, the opposition argued that any broad presidential authority to suspend or restrict immigration should be limited to times of war or declarations of national emergency. ${ }^{129}$ Furthermore, and as formally introduced in the rival HumphreyLehman omnibus immigration bill on March 12, 1952, the opposition argued that if the President was to be granted the power to suspend or restrict entry, he should also be empowered to temporarily admit aliens when in the country's interest. ${ }^{130}$ As this rival bill languished in McCarran's Judiciary Committee, the opposition turned to amendments in the House and Senate to try and insert the same language into McCarran-Walter.

\section{The Multer Amendment Debate}

In the final House deliberations over amendments to McCarran-Walter on April 25, 1952, Multer introduced a two-part amendment to Section 212(e). The first limited presidential authority to suspend alien entry by proclamation, replacing "Whenever the President finds that the entry of any aliens or of any class of aliens into the United States would be detrimental to the interests of the United States [emphasis added]" with "When the United States is at war or during the existence of a national emergency proclaimed by the President and [emphasis added]." ${ }^{131}$ The second part of the amendment proposed that when under the same conditions of war and national emergency "the President finds the entry or any aliens or any class of aliens into the United States would promote the interests of the United States, or is necessary to provide sanctuary to persecuted aliens or any class of aliens and would not be contrary to the best interests of the United States, he may by proclamation and for such period as he shall deem desirable, suspend such restrictions on the entry of aliens for temporary residence as he may deem appropriate [emphasis added]."132

Four House members spoke against the amendment. Explicitly and implicitly, their underlying concern was the threat posed by refugees. Representatives Thomas A. Jenkins (R-OH) and Richard W. Hoffman $(\mathrm{R}-\mathrm{IL})$ viewed the second part of the amendment as empowering the President to "admit additional millions of aliens" that would be unlikely to ever leave. ${ }^{133}$ Representative Charles Halleck (R-IN) observed that the amendment would allow the President to end-run Congress and the limits on refugee admissions agreed to under the Displaced Persons Act. ${ }^{134}$ Multer acknowledged that this was 
in fact the case, though "only at certain times for limited periods." 135 In effect, the proposed language in the second part of the amendment would explicitly authorize action along the lines of the controversial steps to aid displaced persons taken by Roosevelt in 1944 and Truman in 1945 but on a potentially much larger scale.

Walter was the most vehement in his opposition and the only one to explicitly defend the original language of Section 212(e). He began by chiding Multer for arguing that "the President should not have the power to exclude; then in the same breath he urges that we give the President the power to admit."136 This argument was a response to the earlier efforts of the opposition to remove the subsection entirely from McCarran-Walter rather than addressing the more nuanced rearguard position. For Walter, the fact that the Multer amendment placed the same limiting conditions of war and national emergency on exclusion and admission mattered little. Walter argued further the presidential power to suspend entry under 212(e) was necessary to address emergency conditions such as an epidemic of "communicable diseases" in an alien source country or during "a period of great unemployment" in the United States where it would be "impossible for Congress to act" swiftly enough. ${ }^{137}$ Years later, the Ninth Circuit's December 2017 ruling in the travel ban case used Walter's statement to suggest that the original congressional intent behind 212(e) was for a narrow granting of presidential authority limited to periods of "exigency" where Congress would be "unable to act in timely manner, thus necessitating swift presidential action." 138 In turn, the U.S. Supreme Court in June 2018 rejected the lower court argument as emphasizing an isolated floor statement over what it interpreted as the clear indication of broad congressional intent in the language of the subsection itself. Writing for the majority, Justice John Roberts noted: "When Congress wishes to condition the exercise of executive authority on the President's finding of an exigency or crisis it knows how to say just that." 139

Yet in exploring intent it is instructive to look further at the entire debate over the amendment, something neither the Ninth Circuit nor the Supreme Court did in the travel ban cases in 2017 and 2018. Walter's examples in defense of the subsection were flawed. Existing law from 1917 as retained under McCarran-Walter in Section 212(a) already allowed for the exclusion of aliens "afflicted ... [with] any dangerous contagious disease" and those likely to become a public charge such as "paupers, professional beggars, or vagrants." Moreover, the bill had added new language to the same section excluding aliens seeking entry as "skilled or unskilled labor" where "sufficient workers" already existed in the United States or the "wages and working conditions" of such workers would be "adversely" affected. ${ }^{140}$ In effect, the mechanisms to address both of Walter's scenarios were already in place without 212(e). However, as the McCarran subcommittee had noted repeatedly since the late 1940s, displaced persons posed threats of disease and economic disruption along with the greater challenges of crime and subversion and were gaining entry to the United States despite laws on excludable classes. ${ }^{141} \mathrm{~A}$ constant theme in the subcommittee's hearings was that efforts at tightening legislation and its implementation had failed due to the influence of the supporters of displaced persons. The Multer amendment reaffirmed this concern.

Multer and Celler did not challenge the accuracy of Walter's exigency arguments. Instead, they contended that the first part of the amendment was a necessary corrective to the "broad power" to restrict alien entry in 212(e). When Halleck asked Celler if he would be less "concerned" if he could 
assure "a President that could not do any wrong," Celler replied that they likely shared a concern of any President having a "blank check" over immigration or "unlimited power on any subject." Celler pointedly noted Halleck's concerns over what Truman had done "recently" alluding to his controversial seizure of steel mills by Executive Order earlier in the month. ${ }^{142}$ This argument fell on deaf ears. Multer and Celler also tried to drop the controversial second part of the amendment from further consideration. Walter successfully objected to such a move, noting that "one amendment" with both of its parts was under consideration, and the amendment was rejected. ${ }^{143}$

\section{The Package Deal}

The second incident has received no attention from either scholars or the courts. On May 22, 1952, during the final day of the Senate floor debate, McCarran announced that he and Humphrey had reached a deal. They had discussed "the 153 to 157 amendments" to the omnibus immigration bill S. 2550 and had reached an agreement on twenty-one "minor, technical amendments." McCarran noted that he had agreed further that the amendments "may go to conference" and that he "would be willing to accept those amendments en bloc" if so approved by the Senate. ${ }^{144}$ Humphrey formally introduced the package of amendments reaffirming that they were "technical in nature," that they had been "carefully checked by the respective staffs" and those "Senators who are particularly concerned," such as Lehman. ${ }^{145}$ When asked by Humphrey to comment further, McCarran repeated that he had accepted amendments "which had been offered and did not change the policy or theme of the bill." 146 McCarran also reminded Humphrey, "the worth of the amendments will be considered carefully" in conference and might "not fit" into the places he intended though "may fit in some place" in the bill. ${ }^{147}$ The Senate approved the McCarran-Humphrey package of amendments without objection. Humphrey then asked and received confirmation that the amendments would be printed individually in the Congressional Record. ${ }^{148}$

Yet aside from McCarran, Humphrey, their staffs, and others alluded to in Humphrey's statement, it is not clear that anyone else at the time had read what had been proposed. Senator Leverett Saltonstall (R-MA) was the lone voice who commented on the proposal to approve the twenty-one amendments en bloc, and he simply asked for confirmation that they had all been agreed upon by Humphrey and the Judiciary Committee. ${ }^{149}$ If the amendments had been read on the Senate floor, it would have quickly become apparent that the package contained not only technical modifications but also some "significant changes" to McCarran-Walter. ${ }^{150}$ Of particular note, the sixth change in the McCarranHumphrey deal proposed "in subsection 212(e) to strike out 'Whenever' and insert in lieu thereof: 'When the United States is at war or during the existence of a national emergency proclaimed by the President and."'151 In short, this was the part of the same fallback language demanded by the opposition since 1951 and that had failed in the House during the deliberations over the Multer Amendment.

One interpretation of McCarran's acceptance of such a change was that two years after the subsection's drafting by the immigration subcommittee he no longer saw the language as that important. Although the alien threats remained, passage of the omnibus immigration bill was paramount. In a letter and fact sheet sent to Eastland in early May, McCarran had pointed to critical components of the bill under siege by opponents and the need for the bill's passage. He did not mention the language of Section 212(e). ${ }^{152}$ In addition, compared to McCarran's preferred presidential 
candidate, the restrictionist Senator Richard Russell (D-GA), neither of the leading contenders at the time for the upcoming 1952 elections, Dwight D. Eisenhauer and Estes Kefauver, were likely to invoke 212(e). ${ }^{153}$ Thus, as McCarran had noted, the package deal contained only minor adjustments.

However, a more plausible interpretation is that McCarran's acceptance of the revision was an empty, tactical concession to facilitate the bill's passage in the Senate. His comments to Humphrey regarding what could take place in conference support this view. Walter's response to the Multer amendment the month before had also signaled that the technical change would not survive the House. McCarran handpicked the conference committee, "excluding liberals and moderates all together," further assuring his desired result. ${ }^{154}$ Unsurprisingly, the technical amendment to Section 212(e) was not mentioned in either the Senate or House discussions of the conference committee report and did not appear in the conference version of McCarran-Walter. ${ }^{155}$ Section 212(e) as originally written in 1950 remained intact.

\section{CONCLUSION}

The language of Section 212(e) of the Immigration and Nationality Act as passed in 1952 contains a sweeping authorization of presidential discretion to restrict alien entry into the United States. The subsection empowers the President to backstop existing law on classes of excludable aliens and override provisions on admissible aliens. Despite such authority and the potential for closing off all alien entry, the origins of this subsection have been understudied by scholars and largely overlooked by the courts. That the language of what would become the 1952 INA was initially drafted in toto by McCarran's immigration subcommittee is well known. Yet the origins and subcommittee intent behind Section 212(e) are much less so.

Drawing on a detailed analysis of the report accompanying McCarran's 1950 omnibus immigration bill, this article reveals how the subcommittee modeled Section 212(e) on presidential discretionary authority over alien entry in the sixth proviso of the 1917 Immigration Act, presidential authority to restrict alien entry by proclamation under the May 1918 Wartime Measure, and a selective interpretation of Supreme Court precedent on congressional and presidential authority over alien entry. Insights into the reasons why the McCarran subcommittee added the language of Section 212(e) to the 1950 omnibus immigration bill lie in concerns with refugees and subversives. Casting a wider exploratory net beyond the subcommittee report, the article reveals the antipathy of the subcommittee to particular types of displaced persons and foreign government officials. In Jewish refugees, the subcommittee saw rising numbers of unassimilable aliens prone to criminal and subversive behavior. Moreover, their access had been facilitated by questionable presidential initiatives, flawed legislation, and implementation of vetting processes by a tainted and suspect Displaced Persons Commission. In foreign officials, the subcommittee saw the expansion of Communist networks as aliens used diplomatic privileges to exert direct influence over subversive activities in the United States.

Existing law even as refined under other provisions of the McCarran omnibus bill would not be enough to address these threats. A future restrictionist president would require broader authority over curtailing alien entry. For McCarran and the subcommittee, there was no confusion or need for further 
clarification as to what the language of Section 212(e) entailed. As Celler feared, such authority was intended to be an untrammeled right.

H. Richard Friman

Marquette University

H. RICHARD FRIMAN is Eliot Fitch Professor for International Studies, Professor of Political Science, and Director of the Center for Transnational Justice at Marquette University, Milwaukee. His research focuses on the intersection of the licit and illicit global economies, including the politics of (im)migration and crime. h.r.friman@marquette.edu

I thank Peter Andreas, Julia Azari, Lowell Barrington, Alice Friman, Julie Friman, Bruce Gentry, Audie Klotz, Barrett McCormick, Paul Nolette, Phil Rocco, and the anonymous reviewers at JPH for their comments and suggestions. This manuscript expands on my article in The Monkey Cage in The Washington Post, "Trump's travel ban is built on a law meant to 'protect' the U.S. from Jews and communists," 22 and 26 June 2017.

\section{NOTES}

1. 98 Cong. Rec. 4123 (1952).

2. Ibid.

3. U.S. Congress, House, Revising the Laws Relating to Immigration, Naturalization, and Nationality, H.R. 5678, Committee on the Judiciary, House, Report No. 1365, 14 February 1952 (hereafter Report No. 1365) (Washington, D.C., 1952), 145.

4. Ibid., 325.

5. 98 Cong. Rec. 4123 (1952).

6. These efforts are discussed in detail below.

7. For example, see Robert A. Divine, American Immigration Policy, 1924-1952 (New Haven, 1957), 164-91; David H. Bennet, The Party of Fear: From Nativist Movements to the New Right in American History (Chapel Hill, 1988), 302-30; Daniel J. Tichenor, Dividing Lines: The Politics of Immigration Control in America (Princeton, 2002), 188-96; Roger Daniels, Guarding the Open Door (New York, 2004), 113-20; Mae M. Ngai, Impossible Subjects: Illegal Aliens and the Making of Modern America (Princeton, 2004), 236-39; Aristide R. Zolberg, A Nation by Design: Immigration Policy in the Fashioning of America (New York, 2006), 311-17; Daniel Kanstroom, Deportation Nation: Outsiders in American History (Cambridge, Mass., 2007), 17375; Carl J. Bon Tempo, Americans at the Gate: The United States and Refugees During the Cold War (Princeton, 2008), 26-33; Duane Tananbaum, Herbert H. Lehman: A Political Biography (Albany, 2016), 355-58. On the origins of changes to Asian exclusion, see also David M. Reimers, Still the Golden Door: The Third World Comes to America (New York, 1992), 14-21, 18, 37-50; Madeline Yuan-yin Hsu, The Good Immigrants: How the Yellow Peril Became the Model Minority (Princeton, 2015), 91-126.

8. Jack Wasserman, "The Immigration and Nationality Act of 1952-Our New Alien And Sedition Law," Temple Law Quarterly 27, no. 1 (Summer 1953): 62-89 (77-78); Divine, American Immigration Policy, 135-40, 164-69, 171, 180-83; Jerome E. Edwards, Pat McCarran: Political Boss of Nevada (Reno, 1982), 132; Tichenor, Dividing Lines, 188-96; Michael J. Ybarra, Washington Gone Crazy: Senator Pat McCarran and the Great American Communist 
Hunt (Hanover, N.H., 2004). 448-51, 463, 479-80, 632-33; Zolberg, A Nation by Design, 311; Bon Tempo, Americans at the Gate, 29.

9. See discussion in Kate M. Manuel, Executive Authority to Exclude Aliens: In Brief, CRS Report No.

R44743, 23 January 2017, https://fas.org/sgp/crs/homesec/R44743.pdf.

10. Ibid., 3-10.

11. 509 U.S. 155 (1993), 172, 187 (quote).

12. Ibid., 187, 200.

13. See 878 F.3d 662 (2017), 687-88; and 585 U.S. 2018, 18-19. I return to the courts' focus and conclusions below.

14. "A Bill to Revise the Laws Relating to Immigration, Naturalization, and Nationality; and for other Purposes," S. 3455, 81st Cong., 2nd sess., Senate, 20 April 1950.

15. David H. Rosenbloom, Building a Legislative Centered Public Administration: Congress and the Administrative State, 1946-1949 (Tuscaloosa, 2000), 7-8, 14-22, 30-41.

16. "Administrative Procedure Act," Proceedings in the House of Representatives, 24 and 25 May 1946, and Proceedings in the Senate of the United States, 12 March and 27 May 1946, 298, https://www.justice.gov/sites/default/files/jmd/legacy/2013/11/19/proceedings-051946.pdf.

17. On the direct contradiction between the McCarran and Walter positions in 1946 with the McCarran-Walter immigration bill, see testimony by Judge Simon H. Rifkind, on 21 March 1951, in U.S. Congress, Revision of Immigration, Naturalization, and Nationality Laws, Joint Hearings Before the Subcommittee of the Committees on the Judiciary, 81st Cong., 1st sess., (hereafter cited as Joint Hearings 1951) (Washington, D.C., 1951), 575.

18. Quotation is from Humphrey, 98 Cong. Rec. 5315 (1952). See also remarks by Lehman, 98 Cong. Rec. 5114 (1952).

19. Memorandum from David D. Lloyd, Administrative Assistant to the President, to President Harry S. Truman, 3 May 1952, https://trumanlibrary.org/whistlestop/study_collections/immigration/.

20. Tichenor, Dividing Lines, 28-45, 176-96. Although McCarran-Walter proponents pointed to the new inclusion of Asians in the national-origins system and the end of restrictions on naturalization as signaling the end of racial exclusion in U.S. immigration law, critics charged that the national-origins system reinforced discrimination against Asians and Southern and Eastern Europeans. For example, see the arguments by McCarran (98 Cong. Rec. 8253 [1952]) and Harry S. Truman, "Veto of Bill to Revise the Laws Relating to Immigration, Naturalization, and Nationality," 25 June 1952. Online by Gerhard Peters and John T. Woolley, The American Presidency Project. http://www.presidency.ucsb.edu/ws/?pid=14175.

21. See Divine, American Immigration Policy, 135-40, 164-69, 171, 180-83; Tichenor, Dividing Lines, 185-96; Ybarra, Washington Gone Crazy.

22. U.S. Congress, Senate, The Immigration and Naturalization Systems of the United States, Report of the Committee on the Judiciary, Report No. 1515, 81st Cong., 2nd sess. (hereafter Report No. 1515) (Washington, D.C., 1950).

23. For example, see Karen Orren and Stephen Skowronek, The Search for American Political Development (New York, 2004).

24. Report No. 1515, 4.

25. 39 Stat. 874 (1917); Report No. 1515, 376, 387 (quote 387).

26. Report No. 1515, 335-413.

27. 42 Stat. 153 (1924), Sec. 3, 4, 11.

28. Report No. 1515, 414-590. 
29. As discussed below, the language reappears in the report's brief appendix summarizing the omnibus immigration bill but as a catchall overriding provision in the section on "Classes of Persons who may Enter the United States" (Report No. 1515, 806).

30. Report No. 1515, 376, 380-81 (quote 380).

31. Ibid., 380. See also Daniels, Guarding the Open Door, 44.

32. Report No. 1515, 380-81.

33. 34 Stat. 898 (1907); Theodore Roosevelt, "Executive Order, No. 589," 14 March 1907, http://www.theodore-roosevelt.com/trexecutiveorders.html; Report No. 1515, 381; Tichenor, Dividing Lines, 127-28.

34. Harry S. Truman, "Executive Order 10009-Revoking in Part Executive Orders No. 589 of March 14, 1907, and No. 1712 of February 24, 1913," 18 October

1948, http://www.presidency.ucsb.edu/ws/?pid=78225; Report No. 1515, 381.

35. Report No 1515, 381.

36. Ibid., 806.

37. As distinct from the provisions on excludable classes under the 1917 Immigration Act. Ibid., 79496.

38. Ibid., 788

39. Ibid., 794.

40. Ibid., 794, see also 395-97.

41. Ibid., 794, see also 396.

42. Ibid., 794. Here the subcommittee cited the Supreme Court's statements to that effect in Knauff $v$ Shaughnessy.

43. For example, see Jeffrey Gorsky, “An Alternative Legal Argument against Trump's Travel Ban.” Law 360, 10 April 2017, https://0-www-law360-com.libus.csd.mu.edu/articles/911744/analternative-legal-argument-against-trump-s-travel-ban. See also the Supreme Court's majority opinion in the travel ban case discussed below.

44. By early 1952 this provision would be shifted to Section 215 in the revised versions of the omnibus bill and in the final INA. See 66 Stat. 163-282 (1952), especially 190-91.

45. Instead the report noted that "it is the belief of the subcommittee that the present laws in regard to enemy aliens are as they should be." Report No. 1515, 406.

46. This absence suggests that the Supreme Court's interpretation of legislative history in June 2018 in the travel ban case was incomplete when it contended that in $§ 1182(f)$ Congress was "borrowing 'nearly verbatim' from the wartime statute" with "one critical alteration-it removed the national emergency standard." See 585 U.S. 19 (2018).

47. The final report was prepared in stages. See "Displaced Persons in Europe," Report of the Committee on the Judiciary pursuant S. Res 137, Report No. 950, 80th Cong., 2nd sess., 2 March 1948 (hereafter Report No. 950) (Washington, D.C., 1948); and references to progress on the final report in "Displaced Persons," Hearings Before the Subcommittee on Amendments to the Displaced Persons Act of Committee on the Judiciary, U.S. Senate, 81st Cong., 1st and 2nd sess., 25 March 1949 ... 16 March 1950 (hereafter Displaced Persons Hearings 1949-50] (Washington, D.C., 1950), 1115.

48. Report No. 1515, 798. The report draws on language from Nishimura Ekiu v United States 142 U.S. 659 (1892).

49. 338 U.S. 542 (1950). On the political details of the Knauff case, see Ybarra, Washington Gone Crazy, 629-32; and 96 Cong. Rec. A1704-1705, A2178-2179, A3750-3751 (1950).

50. Report No. 1515, 798; 232 U.S. 88 (1914). 
51. Ibid. The subcommittee report used the court's language word-for-word with citation but without quotes.

52. This is evident by the absence of citations to Knauff compared to those appearing in the last chapters of the report.

53. Report No. 1515, 336. 130 U.S. 581 (1889) states: "The power of the legislative department of the government to exclude aliens from the United States is an incident of sovereignty which cannot be surrendered by the treaty making power."

54. Report No. 1515, 336.

55. Ibid., 788.

56. Ibid., 799. These recommendations included the exclusion of "members of the Communist and other totalitarian parties," those belonging to groups that advocate doctrines of totalitarianism, members of front organizations, and those "known" or believed to be likely to engage in subversive activity (799-800).

57. Ibid., 523-25, 797-801.

58. Divine, American Immigration Policy, 92-109; Tichenor, Dividing Lines, 159-67; Daniels, Guarding the Golden Door, 71-80. Bon Tempo, Americans at the Gate, 13-18.

59. Rebecca Erbelding, Rescue Board: The Untold Story of America's Efforts to Save the Jews of Europe (New York, 2018), 11-13, 29-45, 52-56, 140-51; Franklin D. Roosevelt: "Executive Order 9417 Establishing the War Refugee Board," 22 January 1944. Online by Gerhard Peters and John T. Woolley, The American Presidency

Project. http://www.presidency.ucsb.edu/ws/?pid=16540. See also Bon Tempo, Americans at the Gate, 15-21; Richard Breitman and Allan J. Lichtman, FDR and the Jews (Cambridge, Mass., 2013), 262-75.

60. 90 Cong. Rec. 5787 (1944). See also Harvey Strum, "Fort Ontario Refugee Shelter, 1944-1946," American Jewish History 73, no. 4 (1 June 1984): 398-421. On Holman, see Howard M. Sachar, A History of the Jews in America (New York, 1992), 479.

61. Harry S. Truman, "Statement and Directive by the President on Immigration to the United States of Certain Displaced Persons and Refugees in Europe," 22 December 1945, Online by Gerhard Peters and John T. Woolley, The American Presidency

Project, http://www.presidency.ucsb.edu/ws/?pid=12253.

62. Divine, American Immigration Policy, 113.

63. Ibid., 113-29; Tichenor, Dividing Lines, 181-88; Daniels, Guarding the Golden Door, 104-9.

64. On Senate Resolution 137, see Report No. 1515, 1-2, 803-4; and Ybarra, Washington Gone Crazy, 462.

65. Report No. 1515, 3.

66. Report No. 950, 15-16, 20, 25-27. See also statements by Revercomb in 94th Cong. Rec. 6177, 6180-81 (1948); and Divine, American Immigration Policy, 119-20.

67. "To Permit Certain Displaced Persons under 14 years of Age orphaned as a result of World War II to enter the United States as Non-quota Immigrants," Stenographic transcript of Hearings before the Subcommittee of the Committee of the Judiciary, U.S. Senate, Friday, 18 July 1947, vol 1, S. 830 (hereafter Displaced Persons Hearings 1947), 6, 16, 35-38, 62, 69. Available at https://0congressional-proquest-com.libus.csd.mu.edu/legisinsight?id=HRG-1947-SJS-

0027\&type=HEARING.

68. Divine, American Immigration Policy, 120.

69. See 62 Stat. 1009. 
70. Harry S. Truman, "Statement by the President Upon Signing the Displaced Persons Act," 25 June 1948, Online by Gerhard Peters and John T. Woolley, The American Presidency Project. http://www.presidency.ucsb.edu/ws/?pid=12942.

71. Divine, American Immigration Policy, 135-36.

72. Ybarra, Washington Gone Crazy, 463-65. See also Tananbaum, Herbert H. Lehman, 325.

73. Divine, American Immigration Policy, 138-40; Tichenor, Dividing Lines, 188; Ybarra Washington Gone Crazy, 481-83.

74. For overview, see Divine American Immigration Policy, 130-45; Tichenor, Dividing Lines, 185-88; Ybarra, Washington Gone Crazy, 462.

75. Displaced Persons Hearings 1949-50, 17, 47-48, 148, 211, 218, 332-33, 488-89, 758-59, 848, 1067-69, 1141, 1170.

76. Ibid., 505-6, 520, 585-95, 597-98, 709-10, 758-60, 765, 856-60, 980-81, 1018, 1026, 1048, 1170$72,1201,1204$.

77. Ibid., 317-18, 489-94, 503, 553, 558, 678-80, 881-88, 904-7, 928-31, 983-93, 1020, 1035-36, 1141-42, 1145, 1158-60, 1173-97. On Eastland's positions during the displaced-persons debate, see also Maarten Zwiers, Senator James Eastland: Mississippi's Jim Crow Democrat (Baton Rouge, 2015), 80, 82.

78. Displaced Persons Hearings 1949-50, 293, 687, 712-15, 730, 761-65, 835-38, 1142-43, 1156-57, 1160-64.

79. Ibid., 189-219, 299-333.

80. Ibid., 1123. The primary pushback came from Rosenfield and Celler. See ibid., 195-97, 211-19, 299-334, 1097-1129.

81. Ibid., 1116; "Amending the Displaced Persons Act of 1948," Senate Report No. 1237, 81st Cong., 2nd sess., 25 January 1950.

82. See statement by Arens in Displaced Persons Hearings 1949-50, 1115-16.

83. Report No. 1515, 455.

84. Ibid., 235-36.

85. Ibid., 241.

86. Ibid., 242. See also Divine, American Immigration Policy, 166.

87. Report No. 1515, 452.

88. Tichenor, Dividing Lines, 187; Hsu, The Good Immigrants, 134.

89. Report No. 1515, 427-28.

90. Ibid., 428; Divine, American Immigration Policy, 140; Ybarra, Washington Gone Crazy, 482-83.

91. Ybarra, Washington Gone Crazy, 463-64, 480.

92. Joint Hearings 1951, 431, 448, 587, 623.

93. Ybarra, Washington Gone Crazy, 480-83.

94. Report No. 1515, 781.

95. Ibid., 413, 798-801; See S. 3455 (1950), Sections 212(a)(27-29).

96. Ibid., 387-88, 781-82.

97. 39 Stat. 874 (1917), sec. 3

98. 42 Stat. 153 (1924), sec. 3, 25

99. "The 1945 International Organization Immunities Act," 9 December 1945, Section

7, http://avalon.law.yale.edu/20th_century/decad034.asp.

100. See U.S. Congress, Senate, Communist Activities Among Aliens and National Groups, Hearings Before the United States Senate Committee on the Judiciary, Special Subcommittee to Investigate Immigration and Naturalization, 81st Congress, 1st sess., on S. 1832 to amend the 
Immigration Act of 16 October 1918 as Amended, Part I (10-13 May; 1, 8, 9, 18 June; 15, 16, 27, 28 July; 10-12 August) (hereafter Communist Activities Part I) (Washington, D.C., 1949), 1-2.

101. 95 Cong. Rec. 4993 (1949). Although the bill did not explicitly point to the tenth proviso protections, the loophole was the source of three of the "five distinct problems" the bill was intended to "eliminate." 95 Cong. Rec. 4993-94 (1949).

102. See Communist Activities, Part I, 2-4. This bill explicitly stated that the tenth proviso protections would no longer apply.

103. For example, see Wasserman, "The Immigration and Nationality Act," 62-89 (esp. 65).

104. See S. 1832, Section 3(a-b) in Communist Activities, Part I, 2-4.

105. See S. 1832, sec. 3(c) 4(b) in ibid.

106. Communist Activities, Part I; U.S. Congress, Senate, Communist Activities Among Aliens and National Groups, Hearings Before the United States Senate Committee on the Judiciary, Special Subcommittee to Investigate Immigration and Naturalization, 81st Cong., 1st sess., on S. 1832 to amend the Immigration Act of 16 October 1918 as Amended, Part II (7, 8, 9, 13, 14, 15, 28, 29 September) (hereafter Communist Activities Part II) (Washington D.C., 1949).

107. In contrast to the DPA hearings, Arens only briefly explored the issue of Communist subversives gaining access to the United States as refugees (Communist Activities, Part I, 37-38). Similarly, when a witness responded to a question on Communist influence over groups in the United States by referencing "the Jewish group" and "Jewish controlled unions," Arens followed up with only a hypothetical as to the extent to which foreign born were likely to be leaders of a "foreign language group" (Communist Activities, Part II, 474-75).

108. Communist Activities, Part I, 37, 109-23, 371-84; Communist Activities, Part II, 474-75, 787, 798.

109. Communist Activities, Part I, 329-33.

110. Ibid., 163-77.

111. Ibid., 297-329, especially 306, 309-10, 325-26. On the testimony by State officials, see 171-72, 335-70.

112. Ybarra, Washington Gone Crazy, 466-78. From the standpoint of McCarran and the subcommittee, the tour was necessary to obtain vital information as to the extent of fraud and other challenges posed by refugee access under the DPA. For example, see Classified Incoming Message: Senator McCarran to Department of Army Washington, D.C., for U.S. Senators James O. Eastland et al., 7 October 1949, in Eastland File 4 Subseries 9, Box 3, Folder 5, James 0. Eastland Collection, University of Mississippi.

113. Report No. 1515, 781-87, 788-98; Divine, American Immigration Policy, 162.

114. "Subversive Aliens," CQ Almanac 1950 (Washington, D.C., 1951), 422.

115. Report No. 1515, 797-98.

116. Ibid., 523-24. This language would appear in Section 101 (15) (A) (i-iii), (G) (i-iv) of the omnibus immigration bill.

117. Report No. 1515, 524, 800.

118. Ibid., 524, 800.

119. Ibid., 524, 800. This language would appear in Section 102 (1) of the omnibus immigration bill.

120. Since 1941, U.S. consular and diplomatic officials had been authorized by law to deny issuing visas and other documents to aliens who the official "knows or who has reason to believe" was seeking "to enter the United States for the purpose of engaging in activities which will endanger the public safety of the United States" (55 Stat.252 [1941]). However, the subcommittee did not see this law as applying to tenth proviso aliens. Report No. 1515, 791-93. 
121. Report No. 1515, 800-801. The former standard applied to all other tenth proviso aliens. But the "principal resident representatives of foreign government members of international organizations, accredited resident members of their staffs, and members of their families" were exempt from the latter. The "servants, attendees, and personal employees" of foreign government and international organization officials were subject to exclusion on grounds of subversion and any of the other provisions applicable to excludable classes (ibid., 523-24, 800801).

122. Report No. $1515,806$.

123. Ibid.

124. Ibid. McCarran's staff would add these same-tenth-proviso revision measures as Section 22 of his internal security bill, S. 4037, in August 1950. But the language of Section 212(e) was not added to the security bill or the final 1952 Internal Security Act. See Divine, American Immigration Policy, 161; Ybarra, Washington Gone Crazy, 485-534, 640; "Note: The Internal Security Act of 1950," Columbia Law Review 52, no. 5 (1951): 606-60 (esp. 629-34).

125. See 878 F.3d 662 (2017), 687-88; and 585 U.S. 2018, 18-19.

126. Subversive Aliens, 422; Ybarra, Washington Gone Crazy, 493-506.

127. McCarran introduced the revised S. 716 in January 1951, S. 2055 in August 1951, and S. 2550 in January 1952. For a broad overview of this progression, see "Immigration and Nationality

Act." Congressional Quarterly Almanac, 1952 (Washington, D.C., 1953), 154-60.

128. The exception being the Multer amendment debate in the House discussed below.

129. For example, see Joint Hearings 1951, 431, 438, 587, 623; Report No. 1365, 326; and U.S.

Congress, Senate, "Minority View," Revision of Immigration and Nationality Laws, S. 2550,

Senate Committee on the Judiciary, Report No. 1137, 29 January 1952 (Washington, D.C., 1952), 4; 98 Cong. Rec. 5090, 5114 (1952).

130. 98 Cong. Rec. 2142 (1952).

131. Ibid., 4423.

132. Ibid.

133. Ibid., 4423, 4425.

134. Ibid., 4423.

135. Ibid.

136. Ibid.

137. Ibid. Two days earlier Walter had responded to Celler's critique of the broad authority proposed in 212(e) by noting that the authority applied only "when the entry of an alien would be detrimental to the interest of the United States." When Celler asked for clarification as to "what is meant by 'detrimental'" Walter did not reply. Ibid., 4304-5.

138. 878 Fd.3 687-88 (2017).

139. In the court's opinion, when compared to statutory evidence "'[F]loor statements by individual legislators rank among the least illuminating forms of legislative history."' 585 U.S. 19 (2018).

140. These provisions would become Sections 212(a)(6), (8) (14) of the 1952 INA. See also Report No. 1515, 337-50, 358-63, 573-86.

141. On issues of disease and economic burdens caused by refugees, see Displaced Persons Hearings 1947, 38, 62; Displaced Persons Hearings 1949-50, 161-63, 456-58, 555, 788; Divine, American Immigration Policy, 120.

142. The implicit reference here, made explicit by Hoffman, was to Truman's actions against the steel industry in early April that would lead to the Youngstown Steel case before the Supreme Court. 98 Cong. Rec. 4424-25 (1952). 
143. Ibid., 4427.

144. Ibid., 5756.

145. Ibid., 5757.

146. Ibid., 5757-58.

147. Ibid., 5757.

148. Ibid.

149. Ibid. In statements later in the day on behalf of his own amendment, Senator Wayne Morse (R$\mathrm{OR}$ ) reiterated his opposition to Section 212(e), making no mention that the language had been changed with the McCarran-Humphrey deal. 98 Cong. Rec. 5788 (1952).

150. On recognition by members of the Truman administration that the change was in fact significant, see "Senate Amendments to McCarran Bill," ca. 1952 Lloyd files (Wrethram Gathright, Legislative Affairs Division, Bureau of the Budget), Immigration Bills, Truman Library, Immigration Policy: President Truman's Veto of the McCarran-Walter Act, Documents 1952, available at https://www.trumanlibrary.org/whistlestop/study_collections/immigration/documents/inde x.php?documentdate=1952-00-00\&documentid=B50_07-10\&pagenumber=1.

151. 98 Cong. Rec. 5758 (1952).

152. Pat McCarran to James O. Eastland, 6 May 1952. Eastland File Series 1, Subseries 18, Box 7, Folder 11. James O. Eastland Collection, Archives and Special Collections, J. D. Williams Library, University of Mississippi.

153. Edwards, Pat McCarran, 171-72; Gilbert C. Fite, Richard B. Russell Jr., Senator from Georgia (Chapel Hill, 1991), 287.

154. Ybarra, Washington Gone Crazy, 639. On the Senate side, McCarran included himself, Eastland, and Herbert R. O'Conner (D-MD), all of whom had served on the immigration subcommittee in drafting the original bill and report. For the list of participants, see 98 Cong. Rec. 6986 (1952).

155. 98 Cong. Rec. 6947-91, 7016-19 (1952).

\section{REFERENCES}

Divine Robert A., American Immigration Policy, 1924-1952 (New Haven. 1957)., 164-91;

Bennet David H., The Party of Fear: From Nativist Movements to the New Right in American History (Chapel Hill. 1988)., 302-30;

Tichenor Daniel J., Dividing Lines: The Politics of Immigration Control in America (Princeton. 2002)., 188-96;

Daniels Roger, Guarding the Open Door (New York. 2004)., 113-20;

Ngai Mae M., Impossible Subjects: Illegal Aliens and the Making of Modern America (Princeton. 2004)., 236-39;

Zolberg Aristide R., A Nation by Design: Immigration Policy in the Fashioning of America (New York. 2006)., 31117 ;

Kanstroom Daniel, Deportation Nation: Outsiders in American History (Cambridge, Mass. 2007)., 173-75;

Bon Tempo Carl J., Americans at the Gate: The United States and Refugees During the Cold War (Princeton. 2008)., 26-33;

Tananbaum Duane, Herbert H. Lehman: A Political Biography (Albany. 2016)., 355-58. On the origins of changes to Asian exclusion, see also

Reimers David M., Still the Golden Door: The Third World Comes to America (New York. 1992)., 14-21, 18, 3750;

Hsu Madeline Yuan-yin, The Good Immigrants: How the Yellow Peril Became the Model Minority (Princeton. 2015)., 91-126. 
Ybarra Michael J., Washington Gone Crazy: Senator Pat McCarran and the Great American Communist Hunt (Hanover, N.H. 2004). 448-51, 463, 479-80, 632-33;

Rosenbloom David H., Building a Legislative Centered Public Administration: Congress and the Administrative State, 1946-1949 (Tuscaloosa. 2000)., 7-8, 14-22, 30-41.

Orren Karen, and Skowronek Stephen, The Search for American Political Development (New York. 2004).

Breitman Richard, and Lichtman Allan J., FDR and the Jews (Cambridge, Mass. 2013)., 262-75.

Sachar Howard M., A History of the Jews in America (New York. 1992)., 479.

Zwiers Maarten, Senator James Eastland: Mississippi's Jim Crow Democrat (Baton Rouge. 2015)., 80, 82.

Fite Gilbert C., Richard B. Russell Jr., Senator from Georgia (Chapel Hill. 1991)., 287. 